\title{
Comparison of subacute and delayed free flap reconstruction in the treatment of open lower extremity fractures
}

\author{
나 Hakan Arslan, M.D., ๑ Anıl Demiröz, M.D.
}

Department of Plastic, Reconstructive and Aesthetic Surgery, İstanbul University Cerrahpaşa Cerrahpaşa Faculty of Medicine, İstanbul-Turkey

\begin{abstract}
BACKGROUND: Although early free flap coverage for lower extremity traumatic defects has been recommended by several au-thors, it is often not practical due to associated patient injuries or logistics. The aim of this study was to evaluate the impact of suba-cute and delayed surgical timing on flap success.

METHODS: A retrospective analysis of adult patients who underwent a microsurgical free flap operation between 2007 and 2012 following lower extremity trauma was performed. The patients were divided into 2 groups according to the time period between the injury and the free flap operation: a subacute group (flap performed 10 to 29 days after injury) and a delayed repair group ( $>30$ days after injury). The details of patient demographics, the mechanism of injury, timing from operation to discharge, minor and major complications, and flap failure rates were evaluated and compared.
\end{abstract}

RESULTS: The study included 35 patients who underwent 37 free flap operations. A total of 20 patients were operated on 10 to 29 days after the injury (subacute repair group), and 15 patients were operated on more than 30 days after the injury (32-92 days) (de-layed repair group). No significant correlation was found between the timing of the reconstruction, flap failure, and complication rates.

CONCLUSION: Both subacute and delayed reconstruction for lower extremity traumatic defects can be performed with favorable results with appropriate wound preparation and precise preoperative planning.

Keywords: Delayed period lower extremity reconstruction; fracture; free flaps; free flap reconstruction in the treatment of open lower extremity fractures; injury; open lower extremity reconstruction with free flap; subacute free flap reconstruction.

\section{INTRODUCTION}

Microvascular free-flap coverage is one of the most commonly employed methods of reconstruction for lower-extremity defects. ${ }^{[1]}$ Although the earlier flap coverage concept has been favored widely in the last decades of the $20^{\text {th }}$ century, ${ }^{[2-5]}$ in daily practice, receiving these patients and preparing them for surgery within the first 3 days following injury is usually impossible. There have been several reports investigating the effect of surgery timing on the complication and flap failure rates, and they conclude that with appropriate wound preparation and good planning, it is possible to get results similar to early surgery with delayed or late reconstruction procedures. ${ }^{[6-8]}$
The aim of this study was to find whether an optimal reconstructive timing exists beyond "early" in clinical practice and to evaluate the results of subacute and delayed period reconstruction procedures for lower-extremity soft tissue defects.

\section{MATERIALS AND METHODS}

We conducted a retrospective review of adult patients, older than 15 years, who underwent microvascular reconstruction of traumatic lower-extremity defects between 2007 and 2012 in a single institute. Patient records were reviewed for demographics, the mechanism of injury, the time from injury to flap repair and from flap repair to discharge, minor and major complications, and flap failure.

Cite this article as: Arslan H, Demiröz A. Comparison of subacute and delayed free flap reconstruction in the treatment of open lower extremity fractures. Ulus Travma Acil Cerrahi Derg 2019;25:188-192.

Address for correspondence: Hakan Arslan, M.D.

İstanbul Üniv.-Cerrahpaşa Cerrahpaşa Tıp Fak., Plastik, Rekonstrüktif ve Estetik Cerrahi Anabilim Dalı, İstanbul, Turkey.

Tel: +90 212 - 4143500 E-mail: hakanarsln@yahoo.com.tr

Ulus Travma Acil Cerrahi Derg 2019;25(2):188-192 DOI: 10.5505/tjtes.2018.28302 Submitted: 02.08.2018 Accepted: 19.10.2018 Online: 14.03.2019

Copyright 2019 Turkish Association of Trauma and Emergency Surgery 
Table I. Etiology of trauvma and free flap characteristics

\begin{tabular}{lccc}
\hline & Subacute & Delay & Total \\
\hline $\begin{array}{l}\text { Mechanism of injury } \\
\text { Motor vehicle }\end{array}$ & 14 & 8 & 22 \\
Pedestrian injury & 1 & 5 & 6 \\
Motorcycle & 5 & 1 & 6 \\
Gunshot wound & - & 1 & 1 \\
Concomitant injury & 9 & 12 & 21 \\
Flap choice & & & \\
Latissimus dorsi & 17 & 6 & 23 \\
Gracilis & 2 & 4 & 6 \\
Rectus abdominis & - & 2 & 2 \\
Anterolateral thigh flap & 3 & 3 & 6 \\
\hline
\end{tabular}

Cohorts were formed according to the time interval from injury to flap repair; 10-29 days was described as subacute and more than 30 days (32-92 days) was described as delayed repair. Other variables were evaluated in each group, and they were compared.

Statistical analyses were performed using MedCalc for Windows, version 15.0 (MedCalc Software, Ostend, Belgium). Descriptive statistics were summarized using frequencies, percentages, mean, and standard deviation (SD). The chisquared test or Fisher's exact test was used to determine differences between the sets of categorical data, and the $t$ test was used for continuous data. Continuous data were expressed as the mean \pm SD. Categorical data were expressed as a frequency and percentage of the total. Significance was defined as $p<0.05$.

\section{RESULTS}

A total of 37 free-flap repair procedures were performed for lower-extremity reconstruction of 35 patients (29 male, six female). The mean age was 30.5 (15-67) years. The most common cause of injury was passenger injuries in motor vehicle accidents $(n=22)$ followed by pedestrian injuries in motor vehicle accidents $(n=6)$, motorcycle accidents $(n=6)$, and gunshot wound $(n=I)$ (Table I).

The patients in the subacute reconstruction group were significantly younger than the delayed reconstruction group $(p=0.003)$.

All patients were consulted for reconstruction at least 3 days after injury. All patients had the Gustilo type IIIB and IIIC fractures of the tibia, fibula, calcaneus, and metatarsal and were treated with negative-pressure wound therapy from the day of admission until the free-flap coverage surgery.

Twenty patients were operated between 10 and 29 days after injury (subacute repair group), and 15 patients were operated 30 days after injury or later (delayed repair group). The mean time between injury and free-flap reconstruction was 35.6 days ( $10-92$ days) overall, 20.7 days ( $10-29$ days) for the subacute reconstruction group and 55.5 days (32-92 days) for the delayed reconstruction group (Table 2 ). The mean time between the free-flap reconstruction and discharge was 37.3 days (I I-90 days) overall, 29.5 days (I I-90 days) for the subacute reconstruction group and 47.6 days (I5-90 days) for the delayed reconstruction group. The hospital stay of the patients in the delayed reconstruction group was significantly longer $(p=0.028)$.

Thirty-one muscle flaps were performed in 29 patients; 23 were the latissimus dorsi (Fig. 2), six were the gracilis, and two were the rectus abdominis muscle flaps (Table I). Anterolateral thigh flap was the fasciocutaneous flap of choice in six patients (Fig. I).

Postoperative complications were seen in 19 patients $(54.3 \%)$. Eleven patients in the subacute reconstruction group (55\%) and eight patients in the delayed reconstruction group (53.3\%) had postoperative complications. There was no significant difference regarding overall complication rates between the groups
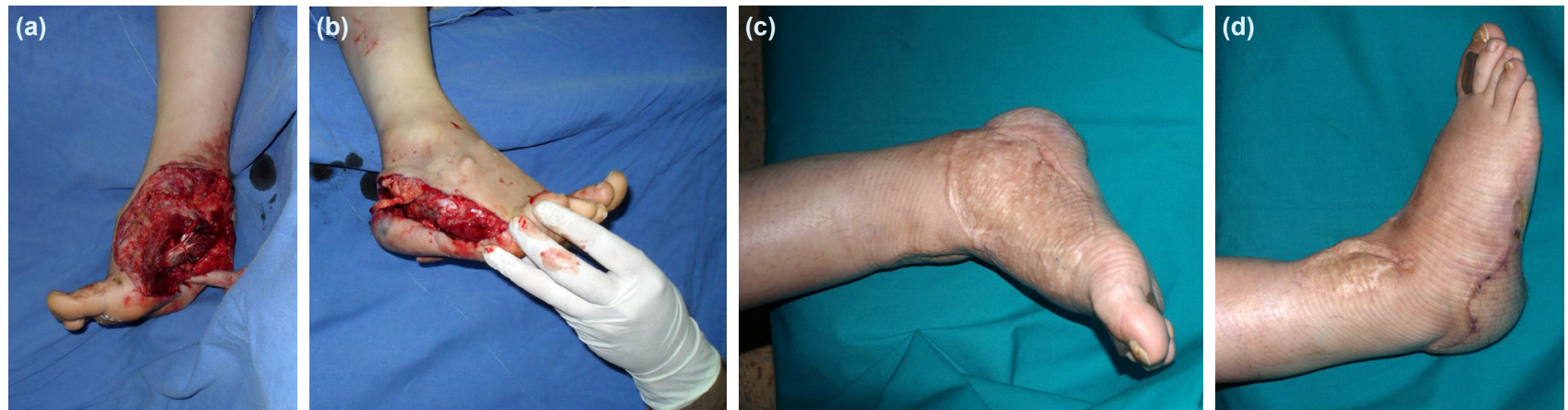

Figure 1. A 21-year-old woman who was involved in a high-speed motor vehicle crash sustained a right ankle metatarsal and calcaneal fracture, extensive degloving injury of complete heel, and plantar area and sacral fracture. Appearance of the right ankle, heel, and medial and lateral plantar wound at initial examination, 24 hours after injury (a, b). Appearance 2 years postoperatively, following anterolateral thigh free-flap surgery (c, d). 

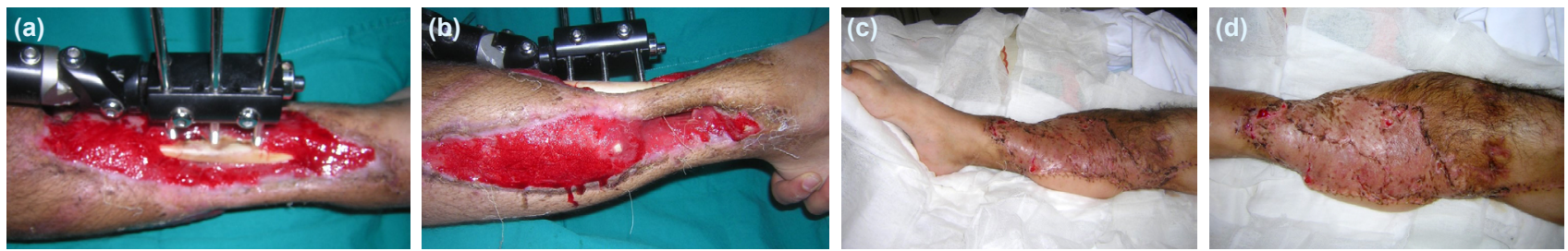

Figure 2. A 32-year-old man who was involved in a motorcycle accident sustained a right tibia fracture with extensive soft tissue and craniofacial injury. Appearance of the right lower extremity at last debridement and 45 days after injury (a, b). Appearance 4 weeks postoperatively, following the latissimus dorsi muscle free-flap surgery (c, d).

$(p=0.922)$. Infection requiring intravenous antibiotics was seen in 3 (15\%) and 2 (13.3\%) patients, partial skin graft failure was seen in 4 (20\%) and 2 (13.3\%) patients, and hematoma was seen in I (5\%) and I (6.7\%) patients in the subacute and delayed reconstruction groups, respectively (Table 2 ).

Six patients were re-operated because of impaired perfusion of the flap; four of these belonged to the subacute reconstruction group (20\%), while the other two belonged to the delayed reconstruction group (13.3\%). Four of the re-explored flaps, two from each group, were lost. One patient in the subacute reconstruction group had serious infection on the operation site, which caused the loss of flap after postoperative $7^{\text {th }}$ day. Five patients overall had total flap loss. One of these patients underwent limb amputation. A second free-flap reconstruction was performed for two of these patients. Other two patients were treated with skin grafts after debridement and wound care. There was no significant difference of flap loss rates between the two groups $(p=1.0)$. In all patients with the Gustilo type IIIB and IIIC fractures, initial fixation was performed using an external fixator. One patient from each group had non-union that required bone grafting. The mean follow-up period was 32 months. Nine patients $(25.7 \%)$ had normal ambulation, while 16 patients (45.7\%) needed a supportive device such as crutches/cane for ambulation. Ten patients $(28.6 \%)$ were routinely wearing orthotic footwear.

\section{DISCUSSION}

The timing of reconstruction procedures for lower-extremity injuries has become controversial. ${ }^{[9]}$ Following the report by Godina favoring early reconstruction, ${ }^{[2]}$ multiple publications have demonstrated a successful delayed soft tissue coverage in recent years due to advances in the accessibility and quality of medical imaging and using advanced techniques, including the negative-pressure wound therapy and refined microsurgical techniques. ${ }^{[6-14]}$ Early reconstruction of lower-extremity defects is usually not feasible due to a delayed referral from the trauma centers, concomitant traumatic injury, medical instability, or operative logistics. ${ }^{[10]}$ Thus, data obtained in the 1970s, 1980s, and early 1990s do not reflect significant clinical advancements and are limited in their applicability to the

Table 2. Outcomes by group

\begin{tabular}{|c|c|c|c|c|}
\hline & Subacute & Delay & Total & $\mathbf{p}$ \\
\hline No. of patients & 20 & 15 & 35 & \\
\hline Age, years* & 25.45 & 37.13 & & $0.003^{*}$ \\
\hline No. of days between injury and flap & 20.7 & 55.5 & & \\
\hline Overall complication, n (\%) & II (55) & $8(53.3)$ & $19(54.3)$ & 0.922 \\
\hline Flap failure, $\mathrm{n}(\%)$ & $3(15)$ & $2(13.3)$ & $5(13.5)$ & 1.000 \\
\hline Pedicle thrombosis/re-exploration, n (\%) & $4(20)$ & $2(13.3)$ & $6(17.1)$ & 0.6 \\
\hline Serious infection, $\mathrm{n}(\%)$ & $3(15)$ & $2(13.3)$ & $5(14.2)$ & 1.000 \\
\hline Partial skin graft failure, $\mathrm{n}(\%)$ & $4(20)$ & $2(13.3)$ & $6(17.1)$ & 0.6 \\
\hline Hematoma, n (\%) & I (5) & I (6.7) & $2(5.7)$ & 0.83 \\
\hline Non-union, n (\%) & I (5) & I (6.7) & $2(5.7)$ & 0.83 \\
\hline Postoperative length of stay, days, mean $\pm S D^{*}$ & $29.5 \pm 4.4$ & $47.6 \pm 6.9$ & 37.3 & $0.028^{*}$ \\
\hline \multicolumn{5}{|l|}{ Functional result } \\
\hline Normal ambulation & $5(25)$ & $4(26.6)$ & $9(25.7)$ & \\
\hline Ambulatory with crutch/cane & $9(45)$ & $7(46.6)$ & $16(45.7)$ & \\
\hline Ambulatory orthotic footwear & $6(30)$ & $4(26.6)$ & $10(28.6)$ & \\
\hline
\end{tabular}

$* \mathrm{P}<0.05 . \mathrm{SD}$ : Standard deviation. 
modern day. Moreover, recent review articles confirmed that a higher number of flaps continue to be performed within the "delayed" time frame (publications from 2008 to 2018). ${ }^{[9,10]}$ Likewise, in our study, the wound management and reconstruction in our series of 35 patients began exclusively in the subacute and delayed reconstruction period beyond 10 days since the initial trauma, due to the concomitant traumatic injury, medical instability, and delayed referral from the trauma center at a mean interval of 35.6 days.

In literature, the reconstructive timing was usually defined as "delay" in a period 3-90 days after injury, and cohorts were labeled as "later" if the reconstructions were done after 90 days post-injury. In our report, we defined the subacute period as 10-29 days and delay period 30-92 days after injury to find whether there is an optimal time for reconstruction within the delay period (3-90 days). Hill et al., ${ }^{[8]}$ reported $21.7 \%$ and $15.8 \%$ flap failure rates in the first 30 days and between 31 and 90 days, respectively, with the overall failure rate of $13.3 \%$. Francel et al. ${ }^{[15]}$ reported a $15 \%$ flap failure rate 0-176 days post-injury. On the other hand, recent review articles found the failure rates $8.8 \%-9.6 \%$ in delayed reconstructions. Our overall flap failure rate of $13.5 \%$ (5 flaps lost in 37 free flaps) was comparable with the previous literature. [8-10,15] In the subacute reconstruction group, a slightly higher failure rate was seen compared to the delay group (I5\% vs. 13.3\%) without any statistical significance.

The infection is the most important complication for the traumatic lower-extremity reconstructions. It may affect not only flap success, but also functional outcomes. A recent metaanalysis of only free-flap reconstruction for lower-extremity injury revealed that the infection rate was $12.7 \%$ within the delay time frame of 3-90 days in 36 articles including a total of $\mathbf{8 6 2}$ free flaps. In another recent systematic review of traumatic lower-extremity wound reconstruction with both free and local flaps, the infection rate was found at $11.6 \%$ within the same time frame. In our study, we found a $13.5 \%$ infection rate in the total group, which is comparable with the previous articles. And it was seen that the infection rate did not significantly change whether the free-flap reconstruction was done within the subacute or delay time frame $(15 \%$ vs. $13.3 \%, p=1)$.

The length of hospital stay is commonly used for calculating the cost efficiency. However, differences in countries and injury types can limit its benefits and usefulness. Haykal et al. reviewed the literature regarding of lower-extremity reconstructions and found that only seven articles mentioned the hospitalization time with an average of 43 days within the delay time frame of 3-90 days, which was comparable with postoperative hospitalization time (37.3 days). Differences between the postoperative length of stay in our subacute versus delay reconstructions ( 29.5 vs 47.6 days, $p=0.028)$ may reflect the younger age in the subacute cohort ( 25.45 vs. 37.13 years, $p=0.003$ ) and the presence of more concomitant injuries in the delay cohort (Table I and 2).
Muscle flaps were the most common types of free flaps in this study. Although fasciocutaneous perforator free flaps provide similar functional results with less donor site morbidities, the practical use of these flaps became more frequent rather recently. ${ }^{[6,17]}$ The retrospective nature of the study was a limiting factor over the flap type preference, which is thought to carry a higher percentage of perforator flaps if performed in a prospective fashion. Nevertheless, considering the previous studies revealing the similar results of perforator flaps compared with muscle flaps, ${ }^{[15,16]}$ this flap type manner is not thought to be an effective factor in our study.

\section{Conclusion}

Nowadays, the majority of free flaps for traumatic lowerextremity reconstruction continue to be performed within the delayed time frame of 72 hours to 3 months worldwide. Patient's general condition, additional injuries, and wound optimization should be considered to designate the timing of reconstruction. There was no optimal reconstruction time frame found in our series, whether it was done within the subacute or delayed reconstruction period after injury.

Conflict of interest: None declared.

\section{REFERENCES}

1. Heller L, Levin LS. Lower extremity microsurgical reconstruction. Plast Reconstr Surg 2001;108:1029-41. [CrossRef]

2. Godina M. Early microsurgical reconstruction of complex trauma of the extremities. Plast Reconstr Surg 1986;78:285-92. [CrossRef]

3. Arnez ZM. Immediate reconstruction of the lower extremity-an update. Clin Plast Surg 1991;18:449-57.

4. Byrd HS, Cierny G 3rd, Tebbetts JB. The management of open tibial fractures with associated soft-tissue loss: external pin fixation with early flap coverage. Plast Reconstr Surg 1981;68:73-82. [CrossRef]

5. Chen S, Tsai YC, Wei FC, Gau YL. Emergency free flaps to the type IIIC tibial fracture. Ann Plast Surg 1990;25:223-9. [CrossRef]

6. Karanas YL, Nigriny J, Chang J. The timing of microsurgical reconstruction in lower extremity trauma. Microsurgery 2008;28:632-4. [CrossRef]

7. Arslan H, Çinar C, Bingöl UA, Yücel OA. Subacute and delayed period microsurgical management of traumatic extremity injuries in pediatric population. Microsurgery 2012;32:527-32. [CrossRef]

8. Hill JB, Vogel JE, Sexton KW, Guillamondegui OD, Corral GA, Shack RB. Re-evaluating the paradigm of early free flap coverage in lower extremity trauma. Microsurgery 2013;33:9-13. [CrossRef]

9. Qiu E, Kurlander DE, Ghaznavi AM. Godina revisited: a systematic review of traumatic lower extremity wound reconstruction timing. J Plast Surg Hand Surg 2018;1-6. [Epub ahead of print]. [CrossRef]

10. Haykal S, Roy M, Patel A. Meta-analysis of Timing for Microsurgical Free-Flap Reconstruction for Lower Limb Injury: Evaluation of the Godina Principles. J Reconstr Microsurg 2018;34:277-92. [CrossRef]

11. Kolker AR, Kasabian AK, Karp NS, Gottlieb JJ. Fate of free flap microanastomosis distal to the zone of injury in lower extremity trauma. Plast Reconstr Surg 1997;99:1068-73. [CrossRef]

12. Parrett BM, Matros E, Pribaz JJ, Orgill DP. Lower extremity trauma: trends in the management of soft-tissuereconstruction of open tibia- 
fibula fractures. Plast Reconstr Surg 2006;117:1315-22. [CrossRef]

13. Steiert AE, Gohritz A, Schreiber TC, Krettek C, Vogt PM. Delayed flap coverage of open extremity fractures after previous vacuum-assisted closure (VAC) therapy - worse or worth? J Plast Reconstr Aesthet Surg 2009;62:675-83. [CrossRef]

14. Rinker B, Amspacher JC, Wilson PC, Vasconez HC. Subatmospheric pressure dressing as a bridge to free tissue transfer in the treatment of open tibia fractures. Plast Reconstr Surg 2008;121:1664-73. [CrossRef]

15. Francel TJ, Vander Kolk CA, Hoopes JE, Manson PN, Yaremchuk MJ. Microvascular soft-tissue transplantation for reconstruction of acute open tibial fractures: timing of coverage and long-term functional results. Plast Reconstr Surg 1992;89:478-87. [CrossRef]

16. Philandrianos C, Moullot P, Gay AM, Bertrand B, Legré R, et al. Soft Tissue Coverage in Distal Lower Extremity Open Fractures: Comparison of Free Anterolateral Thigh and Free Latissimus Dorsi Flaps. J Reconstr Microsurg 2018;34:121-29. [CrossRef]

17. Cho EH, Shammas RL, Carney MJ, Weissler JM, Bauder AR, Glener $\mathrm{AD}$, et al. Muscle versus Fasciocutaneous Free Flaps in Lower Extremity Traumatic Reconstruction: A Multicenter Outcomes Analysis. Plast Reconstr Surg 2018;141:191-9. [CrossRef]

\section{ORIJINAL ÇALIŞMA - ÖZET}

\section{Subakut ve geç dönem açık kırıklı alt ekstremite yaralanmalarında serbest doku ile rekonstrüksiyonların karşılaştırılması}

\section{Dr. Hakan Arslan, Dr. Anıl Demiröz}

İstanbul Üniversitesi-Cerrahpaşa Cerrahpaşa Tıp Fakültesi, Plastik, Rekonstrüktif ve Estetik Cerrahi Anabilim Dalı, İstanbul

AMAÇ: Alt ekstremite travmatik defektler için erken serbest flep kapsamı birkaç yazar tarafından önerilmesine rağmen, hasta veya lojistik ile ilişkili yaralanmalara bağlı olarak genellikle pratik değildir. Bu çalışmanın amacı, subakut ve geç cerrahi zamanlamanın flep başarısı üzerindeki etkisini değerlendirmektir.

GEREÇ VE YÖNTEM: 2007-2012 yılları arasında alt ekstremite travmasını takiben mikrocerrahi serbest flep operasyonu geçirmiş erişkin hastaların geriye dönük analizi yapıldı. Hastalar, yaralanma ve serbest flep operasyonu arasındaki zaman dilimine göre subakut (yaralanmadan 10 ila 29 gün sonra yapılan flep) ve gecikmiş onarım gruplarına (yaralanmadan 30 gün sonra) ayrıldı. Demografik özellikler, yaralanma mekanizması, operasyondan taburculuğa kadar geçen süre, minör ve majör komplikasyonlar ve flep başarısızlık oranları değerlendirildi ve iki grup arasında karşılaştıııldı.

BULGULAR: Çalışmaya 37 serbest flep operasyonu geçiren 35 hasta alındı. Yirmi hasta yaralanmadan sonra 10 ila 29 gün arasında (subakut onarım grubu), 15 hasta ise 30 gün sonra (32-92 gün) yaralanma veya sonrasında (geç onarım grubu) ameliyat edildi. Rekonstrüksiyon zamanlaması, flep başarısızlığı ve komplikasyon oranları arasında anlamlı bir ilişki bulunamadı.

TARTIŞMA: Alt ekstremite travmatik defektleri için subakut veya gecikmeli rekonstrüksiyon yapılabilinir ve uygun yara hazırlığı ve iyi ameliyat öncesi planlama ile iyi sonuçlar alınabilinir.

Anahtar sözcükler: Açık kırıklı alt ekstremite yaralanmaları; free flepler ile açık kırık onarımları; geç dönem alt ekstremite onarımları; serbest doku ile alt ekstremite onarımları; serbest doku onarımları; subakut dönem serbest doku onarımları.

Ulus Travma Acil Cerrahi Derg 2019;25(2):188-192 doi: 10.5505/tjtes.2018.28302 